E-ISSN : 2549-6581

DOI: 10.21776/ub.JOIM.2021.005.01.4

Artikel Hasil Penelitian

Diterima : 30 Desember 2020

Direview : 26 Februari 2021

Dimuat : April-Juli 2021

\section{OPEN ACCESS}

Journal of Issues in Midwifer

\title{
Pengetahuan dan Praktik Bidan tentang Standar Pelayanan Kehamilan di Era Pandemi Covid-19
}

\author{
Nurul Azizah ${ }^{1^{*}}$, Rafhani Rosyidah ${ }^{2}$ \\ ${ }^{\left.{ }^{*}\right)}$ Pendidikan Profesi Bidan, Fakultas IImu Kesehatan, Universitas Muhammadiyah Sidoarjo, \\ Email: nurulazizah@umsida.ac.id,Tlp : +6281553902006. \\ ${ }^{2}$ Pendidikan Profesi Bidan, Fakultas Ilmu Kesehatan, Universitas Muhamamdiyah Sidoarjo, Email: \\ rafhani.rosyida@umsida.ac.id
}

\begin{abstract}
Coronavirus 2019 (COVID-19) is a highly contagious new type of respiratory disease (pneumonia) caused by coronavirus 2 (SARS-CoV-2). All countries are making various efforts to control covid-19, but there are still many infected victims, so WHO has designated this case as a Covid-19 Pandemic. Pregnant women are more susceptible to viral infections; this is due to changes in the immune system and body anatomy. Pregnancy checks in the hospital will be a significant risk for the threat of covid-19 transmission, while services during pregnancy are essential to avoid complications that can occur during pregnancy. This study aims to identify midwives' knowledge and practice regarding the standard of pregnancy services during the Covid 19 pandemic, using a questionnaire given to midwives as health care workers. The study design used a crosssectional study with a chi-square statistical test to determine health services barriers during the pandemic. They were analyzed descriptively. Samples took with quota sampling, with a total of 30 midwives in Candi Sidoarjo sub-district. The research instrument used a questionnaire. This study indicates that $70 \%$ of midwives have good knowledge but do not implement standard pregnancy care during the pandemic. The analysis results show that there is no relationship between knowledge and standard practice of pregnancy services during the Covid-19 pandemic. Conclusion: Most midwives have good knowledge and do not practice standard pregnancy services during the Covid19 pandemic. Suggestion. The next research is to identify the achievements of the pregnancy service program during the Covid-19 pandemic
\end{abstract}

Keywords: Covid-19 Knowledge, Midwife Practice

\section{ABSTRAK}

Corona virus 2019 (Covid-19) merupakan penyakit pernafasan (pneumonia) jenis baru bersifat sangat menular yang disebabkan corona virus 2 (SARS-CoV-2). Semua negara melakukan berbagai upaya untuk mengendalikan covid-19 namun masih banyak korban yang terinfeksi, sehingga WHO menetapkan kasus ini sebagai Pandemi Covid-19. Wanita dengan kondisi hamil lebih rentan terhadap infeksi virus, hal ini dikarenakan terjadi perubahan pada sistem kekebalan dan anatomi tubuhnya. Pemeriksaan kehamilan di rumah sakit akan menjadi sebuah resiko besar terhadap ancaman penularan covid-19, 
sedangkan pelayanan selama kehamilan sangatlah penting untuk menghindari adanya komplikasi yang dapat terjadi selama kehamilan. Penelitian ini bertujuan untuk mengidentifikasi pengetahuan dan praktik bidan tentang standar pelayanan kehamilan di masa pandemi Covid 19, menggunakan kuesioner yang diberikan kepada bidan sebagai petugas pelayanan kesehatan. Desain penelitian menggunakan cross sectional dengan uji statistik chi-square, untuk mengetahui hambatan pelayanan kesehatan selama pandemi dianalisis secara deskriptif. Pengambilan sampel dengan kuota sampling, dengan total 30 responden. Instrumen penelitian menggunakan kuesioner. Hasil penelitian ini menunjukkan $70 \%$ bidan mempunyai pengetahuan baik namun tidak melaksanakan standar pelayanan kehamilan di masa pandemi. Hasil analisis menunjukkan bahwa tidak ada hubungan antara pengetahuan dengan praktik standar pelayanan kehamilan di masa pandemi covid-19. Kesimpulan sebagaian besar bidan mempunyai pengetahuan baik namun tidak melakukan praktik standar pelayanan kehamilan di masa pandemi covid-19.

Kata kunci: Pengetahuan Covid-19, Praktik Bidan

*Korespondensi:Nurul Azizah. Surel: nurulazizah@umsida.ac.id

\section{PENDAHULUAN}

Pandemi merupakan ancaman serius bagi kesehatan perempuan dan bayi baru lahir. Penyediaan perawatan antenatal, intrapartum, dan postpartum sangat mempengaruhi kondisi kesehatan masyarakat. ${ }^{(1)}$ Perawatan antenatal merupakan komponen penting karena menyangkut kesehatan ibu dan anak yang dikandungnya, dengan penyediaan layanan untuk skrining dan diagnosis, pencegahan, dan penatalaksanaan komplikasi kehamilan, penyuluhan kesehatan, dan promosi kesehatan. Organisasi Kesehatan Dunia telah merekomendasikan setidaknya delapan kontak dengan pasien untuk pemeriksaan kehamilan. (2)

Menurut data yang diambil pada 8 Desember 2019 hingga 20 maret 2020 oleh National Health Commission of China menyebutkan terdapat 118 ibu hamil, sebagian besar (84 orang) diantaranya memiliki hasil PCR positif dan $29 \%$ memiliki pneumonia pada hasil CT Scan, dari 112 pasien diantaranya memiliki gejala simtomatik sedangkan 6 lainnya asimtomatik.
Meskipun jumlahnya cukup banyak, tidak ditemukan angka kematian saat itu karena 92\% merupakan kasus ringan dan 8 persen kasus sedang dengan 1 ibu hamil menggunakan ventilator. Berdasarkan laporan tersebut 68 pasien lahir dengan seksio sesarea, 3 pasien mengalami abortus, 2 kasus kehamilan ektopik, 14 kasus dengan prematuritas dan tidak ada bayi yang mengalami asfiksia. ${ }^{(3)}$ Kasus prematuritas dan kematian bayi pada kehamilan yang terinfeksi COVID-19 terjadi pada pasien dengan komorbid seperti obesitas, diabetes mellitus, hipertensi dan asma. ${ }^{(4)}$

Kasus kehamilan dengan Covid-19 di Sidoarjo menjadi salah satu masalah tersendiri, pada bulan Agustus 2020 didapatkan 8 pasien hamil yang terkonfirmasi Covid-19 dengan pemeriksaan PCR positif. ${ }^{(5)}$ Penanganan kasus Covid-19 ini juga memiliki kendala berupa sedikitnya jumlah rumah sakit rujukan untuk kasus kehamilan dengan Covid-19. Diantara 7 ibu hamil yang datang dengan usia kehamilan 24 minggu, 4 melahirkan prematur, 3 melahirkan secara 
seksio sesarea karena kondisi ibu yang memburuk pada usia kehamilan 26, 28, dan 32 minggu. Bayi yang dilahirkan masing-masing ibu tersebut memiliki berat badan lahir yg sesuai dengan usia kehamilan, 2 bayi dinyatakan mengalami sindrom gangguan pernapasan yang membutuhkan surfaktan, dan satu diantaranya mengalami

bronkopulmonalis. ${ }^{(6)}$ Pandemi dysplasia covid-19 memberikan dampak pada kualitas pelayanan kesehatan maternal dan neonatal karena dikhawatirkan dapat menyebabkan adanya peningkatan morbiditas dan mortalitas ibu dan bayi baru lahir. ${ }^{(7)}$ Dalam situasi ini banyak pembatasan hampir ke semua layanan rutin termasuk pelayanan kesehatan maternal dan neonatal, seperti ibu hamil menjadi enggan ke puskesmas atau fasiltas pelayanan kesehatan lainnya karena takut tertular. Hal tersebut akan mempengaruhi target pencapaian program dalam pemeriksaan kehamilan, kunjungan neonatus, dan lain - lain.

Penelitian ini bermaksud mengkaji pengetahuan bidan terhadap praktik standar Pelayanan kehamilan Masa Pandemi Covid 19.

\section{METODE PENELITIAN} Rancangan/Desain Penelitian

Penelitian ini adalah penelitian kuantitatif dengan metode survey. Desain yang digunakan adalah cross sectional.

\section{Sumber Data}

Data yang digunakan adalah
data primer. Instrumen yang digunakan adalah kuesioner. Dalam penelitian ini responden diberikan pertanyaan seputar pengetahuan standar pelayanan kehamilan di masa pandemi covid-19 dan praktik bidan dimasa pandemi covid-19.

\section{Sasaran Penelitian}

Populasi dalam penalitian ini adalah bidan di Kabupaten Sidoarjo. Sampel dalam penelitian ini adalah bidan yang mempunyai PMB (Praktik Mandiri Bidan) dan aktif/ melayani pasien di masa pandemi covid-19 serta bersedia menjadi responden. Jumlah sampel dalam penelitian ini adalah 30 responden.

\section{Pengembangan Instrumen dan Teknik Pengumpulan Data}

Pengumpulan data dilakukan dengan menggunakan kuesioner. Instrumen yang digunakan untuk pengumpulan data sudah diuji validitas dengan Pearson Product Moment dan reliabilitas dengan Cronsistency Chronbach's Alpha. Nilai uji validitas adalah 0,62 dan nilai uji reliabilitas adalah 0,68 sehingga kusioner ini valid dan reliabel.

\section{Teknik Analisis Data}

Analisis data yang digunakan adalah uji exact fisher dengan tingkat signifikansi $\mathrm{P}<0,05$ karena uji chi square tidak memenuhi syarat.

\section{HASIL PENELITIAN}

Pengumpulan data dilakukan pada tanggal 1 Desember 2020 sampai 7 Desember 2020. Berikut ini adalah hasil penelitian yang diperoleh. 


\section{Tabel 1. Analisis bivariabel praktik pelayanan kehamilan di masa pandemi covid-19}

\begin{tabular}{lccc}
\hline \multirow{1}{*}{$\begin{array}{c}\text { Tingkat } \\
\text { pengetahuan }\end{array}$} & \multicolumn{2}{c}{$\begin{array}{c}\text { Praktik standar pelayanan kehamilan masa } \\
\text { pandemi covid-19 }\end{array}$} & \multirow{2}{*}{ Total } \\
\cline { 2 - 3 } & \multicolumn{2}{c}{ Tidak melaksanakan } & $\begin{array}{c}\text { Melaksanakan } \\
\text { protokol }\end{array}$ \\
\cline { 2 - 3 } & protokol & $6(30 \%)$ & $20(100 \%)$ \\
Baik & $14(70 \%)$ & $5(50 \%)$ & $10(100)$ \\
Cukup & $5(50 \%)$ & $0(0 \%)$ & $0(0 \%)$ \\
Kurang & $0(0 \%)$ & $11(36,7 \%)$ & $30(100 \%)$ \\
Total & $19(63,3 \%)$ & & \\
\hline
\end{tabular}

Uji exact fisher $\mathrm{P}=0,425$

Dari tabel tersebut menyatakan bahwa sebagian besar bidan yang tidak melaksanakan praktik standar pelayanan kehamilan di masa pandemi covid19 berpengetahuan baik, sedangkan yang melaksanakan protokol pelayanan kehamilan sebagian besar berpengetahuan cukup. Dari hasil uji exact fisher didapatkan nilai $\mathrm{P}=0,425$ yang artinya tidak ada hubungan pengetahuan dengan praktik pelayanan kehamilan di masa pandemi covid 19.

\section{PEMBAHASAN}

Kementerian

Kesehatan

Indonesia berupaya untuk tetap memberikan pelayanan kesehatan di masa pandemi covid-19, terutama dalam pelayanan kehamilan. Dengan menerbitkan standar pelayanan kebidanan di era pandemi covid-19 2020, dengan harapan agar praktik pelayanan kehamilan tetap dapat di diberikan dengan baik di masa pandemi.

Hasil penelitian menyatakan bahwa sebagian besar bidan mempunyai pengetahuan yang baik, namun tidak melaksanakan praktik standar pelayanan kehamilan sesuai dengan protokol kesehatan di masa pandemi. Pengetahuan yang baik tidak selamanya diikuti dengan pelaksanaan pelaksanaan perilaku yang baik. ${ }^{(8)}$
Sebuah teori tindakan beralasan mengatakan bahwa sikap mempengaruhi perilaku melalui suatu proses pengambilan keputusan yang teliti dan beralasan. Perilaku tidak hanya ditentukan oleh sikap umum tapi oleh sikap yang spesifik terhadap sesuatu. Perilaku juga dipengaruhi oleh norma subjektif, yaitu keyakinan kita mengenai apa yang orang lain inginkan agar kita perbuat. Sikap terhadap perilaku bersama-sama dengan norma subjektif membentuk suatu intensi atau niat untuk berperilaku tertentu. ${ }^{(9)}$

Meskipun bidan memiliki pengetahuan yang baik, akan tetapi kontrol terhadap perilaku juga dapat mempengaruhi minat untuk berperilaku. Hal tersebut menjadikan tidak semua standar pelayanan kehamilan di masa pandemic covid-19 dilaksanakan oleh bidan. Meskipun diasumsikan pengetahuan dan sikap merupakan predisposisi evaluatif yang banyak menentukan individu berperilaku, akan tetapi pengetahuan dan perilaku seringkali jauh berbeda. Hal ini dikarenakan perilaku tidak hanya dipengaruhi oleh pengetahuan atau sikap semata, akan tetapi oleh berbagai faktor eksternal lainnya. ${ }^{(10)}$

Beberapa alasan muncul dari tenaga medis khusunya bidan dalam memberikan pelayanan 
kesehatan selama pandemi, seperti pembatasan pergerakan dan kontak dengan pasien, takut terinfeksi, dan minimnya peralatan medis seperti alat pelindung diri (APD) sebagai upaya proteksi diri, sehingga membuat para bidan mempunyai beberapa alasan untuk tidak menerapkan standar pelayanan kehamilan di masa pandemi covid19. ${ }^{(11)}$

Pemberian informasi oleh bidan melalui bentuk media interaktif sebagai edukasi kepada ibu hamil sangat penting. Informasi dapat diberikan terkait pencegahan diperlukan untuk mencegah penularan covid-19. ${ }^{(12)}$

Pelayanan kehamilan dapat dilakukan dengan mengikuti standar pelayanan masa pandemi covid-19 dengan penerapan protokol kesehatan. Bidan dapat dapat memberikan pelayanan dengan memonitor secara ketat ibu hamil melalui alat komunikasi misalnya berupa telepon atau WhastApp, terkait keluhan yang dialami atau pada pasien hamil yang terinfeksi. Setiap perubahan pada detak jantung janin harus dipantau dan tindakan darurat dilakukan seperlunya untuk menjaga kesehatan ibu dan bayi, berikut juga pelayanan kesehatan psikologis tidak kalah penting selama pandemi ini. ${ }^{(13)}$

Hasil penelitian menunjukkan bahwa sosialisasi dari dinas terkait tentang standar pelayanan kehamilan di masa pandemi covid19 masih diperlukan. Instansi terkait harus memperhatikan kekhawatiran yang dialami bidan dalam melaksanakan pelayanan kehamilan, sehingga segala hambatan dapat diselesaikan. Hal tersebut penting dilakukan agar bidan dapat melaksanakan pelayanan sesuai dengan standar di era pandemi covid-19.

\section{UCAPAN TERIMAKASIH}

Terimakasih

kepada

Universitas

Muhammadiyah

Sidoarjo yang telah memberikan hibah dana sehingga penelitian ini dapat terlaksana dengan baik.

\section{DAFTAR PUSTAKA}

1. Pitale DL. Antenatal care during the COVID-19 pandemic. Int $\mathrm{J}$ Reprod Contraception, Obstet Gynecol. 2020;

2. World Health Organization (WHO). WHO Recommendations on Antenatal Care for a Positive Pregnancy Experience: Summary. World Heal Organ. 2018;

3. Chen H, Guo J, Wang C, Luo $F$, Yu X, Zhang $W$, et al. Clinical characteristics and intrauterine vertical transmission potential of COVID-19 infection in nine pregnant women: a retrospective review of medical records. Lancet. 2020;

4. Arnaez J, Ochoa-Sangrador C, Caserío S, Gutiérrez EP, Jiménez $M$ del $P$, Castañón $L$, et al. Lack of changes in preterm delivery and stillbirths during COVID-19 lockdown in a European region. Eur $\mathrm{J}$ Pediatr. 2021;

5. Dinas Kesehatan Kabupaten Sidoarjo. Profil Dinas Kesehatan Sidoarjo 2020. Sidoarjo; 2020.

6. Dashraath $P$, Wong JLJ, Lim MXK, Lim LM, Li S, Biswas A, 
et al. Coronavirus disease 2019 (COVID-19) pandemic and pregnancy. Am J Obstet Gynecol. 2020;

7. Westgren $M$, Pettersson $K$, Hagberg H, Acharya G. Severe maternal morbidity and mortality associated with COVID-19: The risk should not be downplayed. Acta Obstetricia et Gynecologica Scandinavica. 2020.

8. Saqlain $M$, Munir MM, Rehman SU, Gulzar A, Naz S, Ahmed Z, et al. Knowledge, attitude, practice and perceived barriers among healthcare workers regarding COVID-19: a cross-sectional survey from Pakistan. J Hosp Infect. 2020;

9. Azwar S. Sikap Manusia: Teori dan Pengukurannya. Sikap Manusia: Teori dan Pengukurannya. 2013.

10. Guyer JJ, Fabrigar LR.
Attitudes and Behavior. In: International Encyclopedia of the Social \& Behavioral Sciences: Second Edition. 2015.

11. Vivilaki V, Asimaki E. Respectful midwifery care during the COVID-19 pandemic. Eur $\mathrm{J}$ Midwifery. 2020;

12. Cabrini L, Landoni $G$, Zangrillo A. Minimise nosocomial spread of 2019-nCoV when treating acute respiratory failure. The Lancet. 2020.

13. Wang $\mathrm{C}$, Pan $\mathrm{R}$, Wan $\mathrm{X}$, Tan $Y, \quad X u$ L, Ho CS, et al. Immediate psychological responses and associated factors during the initial stage of the 2019 coronavirus disease (COVID-19) epidemic among the general population in China. Int $\mathrm{J}$ Environ Res Public Health. 2020; 